\title{
American Studies in Norway: Past and Present
}

\section{(2) OpenEdition \\ Journals}

Electronic version

URL: https://journals.openedition.org/ejas/1083

DOI: 10.4000/ejas.1083

ISSN: 1991-9336

Publisher

European Association for American Studies

\section{Electronic reference}

Ole O. Moen, "American Studies in Norway: Past and Present", European journal of American studies [Online], 1-1 | 2006, document 13, Online since 18 January 2006, connection on 10 July 2021. URL: http://journals.openedition.org/ejas/1083 ; DOI: https://doi.org/10.4000/ejas.1083

This text was automatically generated on 10 July 2021

Creative Commons License 


\section{American Studies in Norway: Past and Present}

1 Norwegian "studies" of America started really more than a thousand years ago, when Leif Ericsson landed in Vinland, his name for that part of New Foundland where his party made quarters around the year A.D. 1000. However, it was not until 1825 that modern mass emigration from Norway to America started in earnest, when a small sailing vessel, the sloop Restaurationen, left the little village of Tysvær on the west coast of Norway, near Stavanger, for New York, carrying a load of 52 Quaker emigrants led by the legendary Cleng Peerson. From 1825 until mass emigration petered out a hundred years later, more than 800,000 Norwegians had left for American shores. Today there are about as many people of Norwegian descent in the United States as in the Old Country, and only Ireland has yielded a higher proportion of its population to America than Norway.

2 Consequently, Norway has had a close relationship with the United States since the mid-nineteenth century, and these relations were strengthened by World War Two and the Cold War years that followed, when Norway's location as neighbor to the Soviet Union made the country strategically vital to the United States as a spearhead of the NATO forces, whose North Command Headquarters were located in Oslo. For these and other reasons America has always held a strong fascination for Norwegians, and it was only natural that when the American Studies movement was introduced to the Nordic countries after World War Two, it first took a firm hold in Norway. At the University of Oslo, the literary scholar Sigmund Skard was appointed to the first chair in American literature in Scandinavia in 1946. And two years later he founded the American Institute at the University of Oslo and acted as its chairman until his retirement in 1973.

History Blazes the Path

3 Initially, the study of the United States was introduced in the history departments. Generally, both research and teaching have been mainly concentrated in three areas: prior to World War Two it was primarily Norwegian emigration/immigration to the United States; then, after the war until the end of the Vietnam War, partly as a consequence of the Cold War, the main focus of interest in American history in 
Norwegian history departments was in foreign policy, the Atlantic community in particular. There was also quite a bit of work done on special domestic issues, such as the history of economics and labor, but mainly by academic journalists, politicians, and government administrators. In the field of teaching, American history, in the main, constituted parts of survey courses in world history. In the late 1960s, the teaching and research in American history was regrettably de-emphasized in most history departments at Norwegian universities, as the study of the USA became "politically incorrect" in these circles, mainly because of the Vietnam War. This in fact created a virtual hiatus in faculty recruitment in this field in history departments at Norwegian universities throughout the 1980s and well into the 1990s.

4 Because of the importance of mass emigration in the nineteenth and the early twentieth centuries, emigration studies naturally dominated Norwegian studies and research regarding the United States in the early years. In the beginning, NorwegianAmerican history was written in the traditional contribution genre: it was important to document that the Norwegian immigrants to the United States had made substantial and positive contributions to American society and culture. It would be fair to say that it was professor Ingrid Semmingsen at the University of Oslo who-with her magisterial bi-volume study, The Way West (1941-1950) - lifted the history of Norwegian migration to America out of the filiopietistic rut and in fact put Norwegian-American emigration/ immigration studies at the forefront of international migration studies.

5 However, Ingrid Semmingsen did not teach and do research in the field of emigrant and immigrant studies only, but worked on a wide range of subjects; in fact her book The Creation of a World Power: A History of the United States (1946) was really the first highquality general history of the American nation written by a Norwegian academic scholar. In 1963, Dr. Semmingsen was appointed to the first chair in American history in the country. Regrettably, when she retired in 1977, her chair in American history was split between Norwegian and American history, and it soon became evident that the new professor would mainly pursue his interest in the former branch of study.

6 Among the pioneers of general American history should be mentioned the seminal figure in Norwegian medieval history, Halvdan Koht (later to be foreign minister in the Norwegian exile government in London during World War Two) who also wrote several books on American history-political, social, economic, and constitutional-from ca. 1910 to the 1920s. His late book, The American Spirit in Europe: A Survey of Transatlantic Influences (1949), was an early assessment of the Trans-Atlantic cross-currents. ${ }^{1}$

7 Norway's vital role in the implementation of the Marshall Plan and later as home of the NATO North Command knit Norway closely to the Atlantic community. Several monographs and theses on Atlantic relations as well as emigration to America originated in the history department of the U. of Oslo in the post-war years down to the mid-1970s. Moreover, The American (later International) Summer School, which had been established at the U. of Oslo in 1947, offered a number of courses on American themes and other courses drawing heavily on American academic traditions in the early years.

8 However, because of the political importance of the United States, American foreign policy remained a subject of academic study at several universities and research institutions even in this nadir period of American history studies, among these the Norwegian Institute of International Affairs and several military research institutions. A case in point is Olav Riste at the Norwegian Institute for Defence Studies, who 
published widely on Norwegian military and political relations with the Atlantic community in the postwar years, in which Norway's relationship with the United States constituted a very central portion. Another dominant scholar in the field of AmericanEuropean relations has been Geir Lundestad (the current Director of the Norwegian Nobel Institute for Peace and a professor of history at the U. of Oslo). His Cold-War studies include The American Non-Policy towards Eastern Europe (1975) and The United States and Western Europe since 1945: from "Empire" by Invitation to Transatlantic Drift (2003).

It is symptomatic, however, that Lundestad, although a traditional historian by training, started his career as professor of American Civilization in the English Department at the University of Tromsø, in 1978. There he had succeeded Torbjørn Sirevåg, also a historian by training (doctoral dissertation on Henry Wallace). Sirevåg had moved into government, assuming the position as head of the Research Division in the Ministry of Education and Research. Later, he took up a position as professor of American Studies at the Norwegian School of Management while holding also an adjunct professorship at the Department of British and American Studies at the University of Oslo. In recent years he has written several textbooks in American Civilization for American Studies programs.

American Studies Surfaces

10 Partly as a result of the political fall-out of the Vietnam War era, from the mid- or late 1960 s to the end of the century, American history-political, social, and cultural-was primarily studied under the auspices of American Studies programs in English departments whose main responsibility was the teaching of English language and English-language literature. As leader of the American Institute (which, together with the British Institute made up the English department for teaching purposes, but remained separate research units), Sigmund Skard subscribed to a broad view of cultural studies, and he was also instrumental in the successful effort to establish the European Association for American Studies (1954). His book American Studies in Europe: Their History and Present Organization (1958) was an early mapping of the American Studies movement in Europe. In 1949 he had published his book American Problems, which indicated a critical perspective on American culture. Among his several dozen books should be mentioned The USA in Norwegian History (1976). ${ }^{2}$

11 Gradually a third branch of study developed within English departments, first known as "American background"-ancillary to the teaching of literature-but which by the mid-1970s had developed into a separate "discipline"-although highly interdisciplinary and diversified-and in 1974 was officially designated American Civilization. It evolved along an almost exponential curve in the 1970s and 1980s and, when the forerunner of the current American Studies Association of Norway (ASANOR, 1993) was established in 1974, the initiative was taken by faculty members of several English departments with financial support from the American Embassy. The first American Studies Seminar, mainly under the auspices of the U.S. Information Service, was held in Trondheim in1977. Since then some thirty American Studies conferences have been held.

12 The U.S. Educational Foundation in Norway (later known as the Fulbright Foundation) has also been a vital force in establishing and maintaining an interest in American Studies in Norway, and in recent years, so-called Roving Scholars for junior and senior high schools-itinerant American scholars visiting schools in all parts of the countryhave proven to be a quite successful venture, extending the reach of the exchange 
program to grade schools. The Norwegian government has demonstrated its support of the Fulbright program by carrying 70 percent of the cost of the exchange programs, which is quite unusual, common practice being for the USA and the individual bilateral partner to share the costs equally.

Dorothy Burton Skårdal's contribution to the field of America Studies should be underlined in particular. She studied under Oscar Handlin at Harvard University, and her doctoral dissertation-which was later published as The Divided Heart: Scandinavian Immigrant Experiences through Literary Sources (1974)-came to serve as a model for a great number of master's theses. She was also an active force in inspiring emigration studies in Denmark and Sweden as well as among local historical societies in Norway. Furthermore, she was instrumental in establishing studies of "return emigration", especially to the southern part of Norway. In recognition of the great value of her work she was made a Knight of the Order of St. Olav by King Olav V.

In this context should also be mentioned a literary scholar and long-time member of the EAAS Board, Orm Øverland of the University of Bergen. Having written his doctoral dissertation, The Making and Meaning of an American Classic : James Fenimore Cooper's The Prairie (1973), at Yale University, he taught American literature at the University of Bergen. In the later years of his career he developed a strong interest in immigrant literature and culture. His book The Western Home: A Literary History of Norwegian America (1996) won him the American Studies Network Book Prize for the Best Book by a European Scholar in 1998. In 2000 he published Immigrant Minds, American Identities: Making the United States Home, 1870-1930. Perhaps most important from a historical point of view is the four-volume collection of immigrant letters, 1836-1888, which he has coedited, entitled From America to Norway: Norwegian Emigrant Letters (1992-2002).

Today courses in American Civilization are offered by most Norwegian colleges and universities. At colleges and teachers' training colleges civilization is taught mainly as "background" to American literature in American Studies programs. In universities the situation is different. As part of the structural reorganization of the study programs at the University of Oslo and its adoption of the Bologna Plan and the ECTS grading system, a strong North-American Studies section has been established under the program in European and American Studies, which is now the stronghold of American Civilization teaching and research in Norway, having four full-time tenured faculty members in the field, one full professor and three associate professors.

16 The program is administered by the Department of Literature, Area Studies and European Languages (ILOS). The full-time associate professors are: Mark Luccarelli (Ph.D. in American Studies, U. of Iowa), specializing in urban and environmental studies and foreign policy studies; Deborah Kitchen Døderlein (Ph.D. in history, U. of Minnesota), women's history, multiculturalism, and film studies; and David Mauk (Ph.D. in history, City University of New York, formerly at Norwegian University of Science and Technology, Trondheim), whose main interest is in immigration history and political studies. The fourth full-time faculty member is professor Ole O. Moen (Ph.D. in American Studies, U. of Minnesota), whose fields of specialization are constitutional history, and political and social history. In addition, literary scholar associate professor Erik Kielland-Lund, who was instrumental in establishing the program, now teaches part-time in the program, since his main obligation is in literary studies. His areas of specialization are "literature and society" and popular culture. Courses offered by ILOS range from general survey courses (some of which are co- 
taught with literature) to specialized courses on the history of foreign relations in a global context, the history of women and minorities; environmental and urban studies; political geography, economics, and institutions; film studies; popular culture; literature and society; immigration studies; legal and constitutional history; and political, social, and cultural history. Also, a number of courses in Canadian Studies are offered as part of the North-American Studies program.

The Field of American Studies Expands

In the new millennium, the history and political science departments at the University of Oslo have rediscovered America, in a manner of speaking. The Department of History has broadened its studies of American history-although still primarily seen in a Norwegian perspective-having launched an ambitious research program, "America in Our Hearts, " which studies perceptions of the USA by Norwegians in a broad historical perspective. The Department of Political Science, many of whose faculty members have done graduate studies at American Univesities, has also strengthened its studies of American society and institutions. In so doing, it is collaborating with ILOS American Civilization faculty members.

At the Norwegian University of Science and Technology, Trondheim, there has been one tenured associate professorship since the early 1990s, Tore Tingvold Petersen (Ph.D. in history, University of Minnesota) whose main fields of interest are diplomatic history, political history, and Native American history. In the English Department (now The Department of Modern Languages), there have been at least one tenured associate professor in American Civilization, for some years two, as well as at least one adjunct professor or instructor. The chief person has been David C. Mauk (now at the U. of Oslo), an immigration historian (Ph.D. thesis on Norwegians in New York, The Colony That Rose from the Sea: Norwegian Maritime Migration and Community in Brooklyn, 1850-1910), who delves in political history as well.

19 At the University of Tromsø, Professor Torbjørn Sirevåg, followed by Professor Geir Lundestad, taught American Civilization, mainly history, from the mid-1970s till the latter assumed his position at the Norwegian Nobel Institute. After Dr. Lundestad's departure, the chair in American Civilization (which was originally created as a combined position in both British and American Civilization) was transferred to British Civilization and given to a scholar with strong literary interests who has dedicated himself exclusively to British Studies. On the other hand, a professor of American Literature, Fredrik Chr. Brøgger, a literary scholar with broad social and cultural interests, has since the 1970s also taught American Civilization and written an important book on the methodology of the field, Culture, Language, Text: Culture Studies within the Studies of English as a Foreign Language (1992).

20 At several regional university colleges there are faculty members specializing in American history and civilization. At Stavanger College, which has recently become Stavanger University, there is Associate Professor Arne Neset, specializing in the history of arts in a social-political context, at Østfold College there are Associate Professor Robert Mikkelsen, a labor and social historian, and Associate Professor Magne Dypedahl, a general Americanist, at Agder College Robert G. Baehr has just retired as a general American Studies scholar, and at Vestfold College, Associate Professor James Godbolt, an American, has written an excellent post-World War Two American history in New Norse (one of two official Norwegian languages, which is based on the Viking tongue), USA $i$ vår tid: trekk frå nyare amerikansk historie (The USA in 
Our Time: Main Currents in Recent American History, 1994). Associate Professor Øyvind Gulliksen at Telemark College, a literary scholar, has done extensive work on Norwegian-American immigrant culture, especially in a local perspective. Associate Professor Rasmus Sunde at Sogndal College has made a thorough study of emigrantion to America from his region. In addition American Civilization is being taught at all teachers' training colleges, primarily in conjunction with American literature.

In response to the restructuring of Norwegian higher education to conform to the Bologna Plan, more interdisciplinary projects and general cooperation among diverse departments are being developed also in the field of American Studies. This may seem a little ironic since at no time since the Vietnam War have Norwegians been so critical of the American government as they are today. On the other hand, hardly in any other European country has American popular culture had such a broad and profound impact, beginning in earnest after World War Two and increasing steadily to the present.

Recent Development

International political developments since the end of the Cold War have had profound repercussions in the field of American Studies in Norway. In the Cold War years, Norway was of vital interest to the United States-mainly for national security reasons -and the U.S. Government was willing to spend considerable sums of money to maintain good relations with Norway. This included generous support of American Studies at all levels. As already mentioned, it was to a great extent thanks to initiatives by the American Embassy that the organization of a Norwegian American Studies movement materialized. With the fall of the Iron Curtain and the end of the Cold War things changed dramatically. Funds that had hitherto been spent in Norway were diverted to areas where they were more needed and where more was to be gained by such investment. It was quite symptomatic that the position of Cultural Attache at the American Embassy in Oslo was moved to Vilnius, Lithuania. Likewise funds in support of national American Studies conferences all but dried up.

The Nordic Association for American Studies had been established in 1959, primarily as a sub-branch of the European Association for American Studies (1954). NAAS had national representatives in each of the five Nordic countries-Denmark, Finland, Iceland, Norway, and Sweden-and established a pattern of biennial conferences on rotation among the member countries. Its first conference was held in Sigtuna, Sweden, in 1961. These conferences received generous financial support from the American embassies in the respective countries as well as scholarly input from Americanists from the USA. In the early 1990s these financial contributions from the US Government to NAAS were being gradually reduced in the same way, if not quite so dramatically as American support of national activities in the field.

In response to the new circumstances after the fall of the Iron Curtain, American Studies scholars in Norway established their own national association, The American Studies Association of Norway (ASANOR) at their annual national conference in Kristiansand, on May 8, 1993. A financial nest egg was created by voluntary contributions from core members, establishing an Endowment Fund, which was later renamed the Sigmund Skard Endowment Fund for ASANOR, which was set up to raise money for scholarships and travel grants, the latter mainly for high-school teachers who receive scant support from their schools to attend national conferences of this kind. Furthermore, a fund-raising drive was launched in order to raise money for the 
operation of the organization. Over the years several other funds have been established, named for other prominent American Studies scholars or donors, in order to attract money to the association. The following scholars have been presidents of ASANOR since its formal founding in 1993: Assoc. Prof. Robert G. Baehr, Agder University College (1992)1993-1996; Assoc. Prof. Arne Neset, Stavanger University College, 1996-1998; Assoc. Prof. Robert Mikkelsen, Østfold University College, 1998-2002 (acting also 2003); and Prof. Per Winther, University of Oslo, 2002- (2003-).

Nearly all of the ventures and initiatives taken by ASANOR were the brainchildren of a driving force in the American Studies movement in Norway, associate professor Robert G. Baehr at Agder University College in Kristiansand, now an emeritus scholar. He was also instrumental in establishing an ASANOR website in 2000, which was upgraded and provided with a new address in 2004, and has been its editor since its inception. His contributions to the success of ASANOR as a functional and vital association can hardly be overstated. As a result of the Norwegian initiative, similar national associations have now been established in the other Nordic countries, and in 2002 the NAAS Constitution was rewritten to square with the new realities.

NAAS is now a vital and functional federation, with a board made up of the presidents of the respective national associations for American Studies and the editor of the NAAS journal, American Studies in Scandinavia, since 2003 Professor Per Winther, chair of the Department of Literature, Area Studies and European Languages at the University of Oslo and since 2004 also President of ASANOR. Professor Orm Øverland of the University of Bergen was editor of the ASIS journal from 1973 to 1985. He was subsequently president of NAAS, 1985-1992. Dr. Øverland has also been a dedicated servant to the EAAS, as a member of the EAAS board, 1976-1981 and Treasurer 1992-1996. Professor Ole O. Moen, the University of Oslo, was Vice-President of ASANOR 1998-2002, President of NAAS, 2001-2003, and the first Secretary General of EAAS, 2002-2006. Dr. Moen has served as Contributing Editor for Norway of the Journal of American History since 1994. In 2003 he was also appointed a member of the Board of International Advisers to the Center for American Studies and Research at the American University of Beirut, Lebanon, and in 2004 he was invited to be the International Adviser to the Center for The Studies of the United States at the University of Belgrade, Serbia and Montenegro. Since 2002 Associate ProfessorDavid C. Mauk, University of Oslo, has been Vice-President of ASANOR and editor of the NAAS Newsletter.

One important feature shared by ASANOR and the Danish Association for American Studies (DAAS) is their inclusion of high-school teachers as bona fide members, in contrast to the national associations of Finland, Iceland, and Sweden. Such a broad membership base enhances closer relations among teachers in secondary schools, colleges, and universities and facilitates coordination of programs and work towards common educational goals on all levels. Of special significance in this context is the pre-conference symposium for teachers, which has been arranged by ASANOR at its annual conferences since the early 1990s.

It should be explained that the reason I have not dealt with literary studies at any length in this survey, is simply that-like the situation in many Western European countries-American literature has been taught as part of English studies, mainly as literary studies rather than American Studies as such, although at the University of Oslo, for example, the teaching of American literature has been closely coordinated 
with the teaching of American Civilization, especially at the lower levels. Central figures here have been Professors Brita Lindberg Seyersted, Per Seyersted, and Per Winther and Associate Professor Erik Kielland-Lund. Per Seyersted also established Canadian Studies as part of the Department program-building impressive library holdings in the process, supported by generous grants from the Canadian Government-and Per Winther now teaches Canadian Literature as well as American literature. At the University of Trondheim (later at Agder College) we find Associate Professor Sigmund Roe, at the University of Bergen Professor Orm Øverland, Associate Professor Øyunn Hestetun, and Zeljka Svrljuga, and at the University of Tromsø. Fredrik Chr. Brøgger. Out of space considerations I have, however, limited my essay primarily to American history and civilization.

The field seems strong at present. Among the new aspects of American Studies is a stronger comparative dimension. This developing trend is strengthened by the new efforts of the universities and colleges to include at least one semester at a university abroad in every student's Bachelor's or Master's program. A great number of exchange contracts have been established between Norwegian and universities and colleges in the United States and Canada in recent years. I an happy to report that students are attracted to North-American Area Studies courses in great numbers. In short, the future prospects of this field of study look bright.

\section{NOTES}

1. (Philadelphia, 1949); Pengemakt og arbeid I Amerika [Money and Labor in America] (1910); Genesis of American Independence

(1910); Den amerikanske nasjon i opphav og reising [The Creation and Rise of the American Nation] (1920).

2. American Studies in Europe: Their History and Present Organization (1958).

\section{INDEX}

Keywords: popular culture, multiculturalism, Film Studies, Bologna, American History, foreign policy, immigration, Vietnam War, women's history, Native American history, American Civilization, old War 